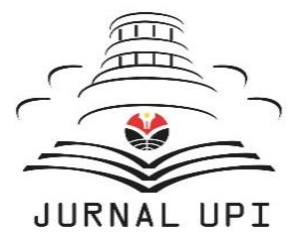

INDONESIAN JOURNAL OF APPLIED LINGUISTICS

Vol. 9 No. 2, September 2019, pp. 263-274

Available online at:

http://ejournal.upi.edu/index.php/IJAL/article/view/20217

doi: 10.17509/ijal.v9i2.20217

\title{
Exploring EFL teachers' English language proficiency: Lessons from Indonesia
}

\author{
Anik Nunuk Wulyani*, Irina Elgort, and Averil Coxhead \\ Department of English, Faculty of Letters, Universitas Negeri Malang, Jalan Semarang 5 Malang, East Java, Indonesia \\ School of Linguistics and Applied Language Studies, Faculty of Humanities and Social Sciences, Victoria University of \\ Wellington, PO Box 600 Wellington 6140, New Zealand
}

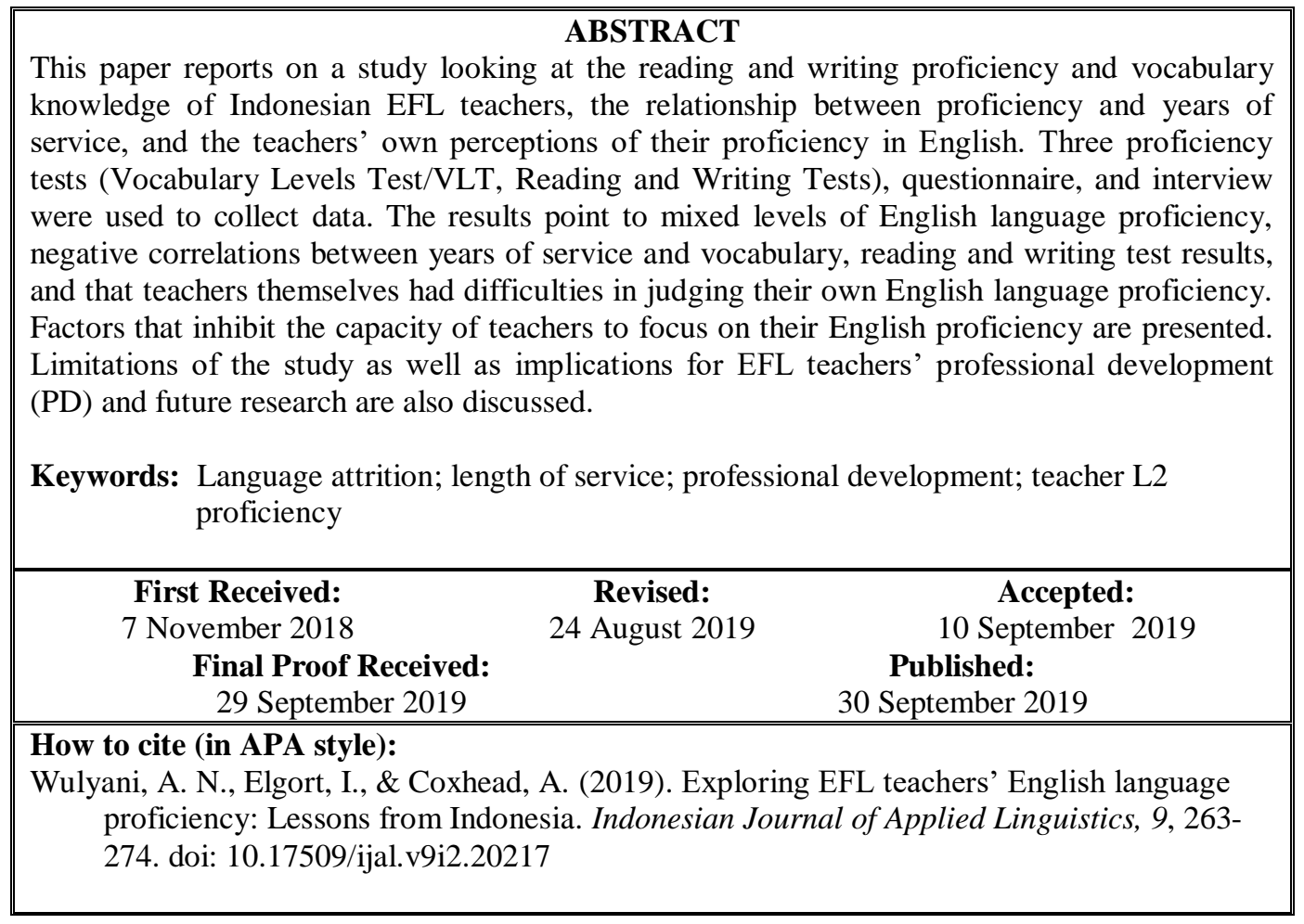

\section{INTRODUCTION}

Having a good command of English plays a pivotal role when one chooses teaching English as her or his profession. In a global context, the issues of foreign language teachers' proficiency have received significant attention (Harvey, Conway, Richards, \& Roskvist, 2010; Richards, Conway, Roskvist, \& Harvey, 2013; Richards, 2017). The estimated target language proficiency in these studies is commonly measured using performance-based tests (i.e. oral and written language assessment) (Richards et al., 2013), while the perceived L2 proficiency, refers to the extent to which a person thinks that she is competent at communicating, is commonly assessed by soliciting her self-report data (i.e. questionnaire or survey) (Harvey et al., 2010 \& Richards, 2017).

In Asia and in Southeast Asia, previous studies also show that the issue of EFL teachers' language proficiency is quite common (Dudzik \& Nguyen, 2015;
Hamid \& Nguyen, 2016; Li \& Baldauf, 2011; Mori, Ming, Nor, Suppiah, \& Imm, 2011). These studies explore both the estimated and perceived target language proficiency of second language teachers, with the exception of Mori et al. (2011) which investigated English language learners' perceived English proficiency. However, little seems to be reported in the literature about EFL teachers' actual and perceived proficiency in English.

In the Indonesian teaching and learning context, English language teachers are required by educational laws to have proper academic qualifications and hold teaching certificates. Having proper academic qualification means that the teacher must hold Bachelor degress in English language teaching. In addition, the status of English as a compulsory subject in some primary schools and most secondary high schools and tertiary education in Indonesia demands qualified EFL teachers (Dardjowidjojo, 2000; Jazadi, 2000; Lauder,

\footnotetext{
* Corresponding Author

Email: anik.nunuk.fs@um.ac.id
} 
2008). That said, it is important to understand that the graduates of English teacher training education should have sufficient English proficiency to teach English effectively in the classrooms. Renandya, Hamied and Nurkamto (2018) state that language proficiency is one of the key components that make up a language teacher's professional knowledge. (p. 622)

Vocabulary research suggests that English as a foreign language learners demonstrate fairly low levels of lexical knowledge. In the Asian context, Nurweni and Read (1999) in Indonesia and Webb and Chang (2012) indicate that learners fail to master even the most frequent 1,000 words of English, even after some years of study. This finding is important, because today's university students could be tomorrow's English language teachers.

Earlier studies in teacher proficiency in Indonesia do not offer a reassuring outlook. Lengkanawati (2005), for example, explored EFL teachers' English ability and readiness to face the implementation of the 2004 Curriculum in West Java, Indonesia, where a score of TOEFL 500 is required for an undergraduate degree in English language teaching. Thirty-eight high school teachers participated in a paper-based TOEFLequivalent test and their average score was 467, i.e., lower than the baseline. In a research project investigating the implementation of Competency-Based Language Teaching (CBLT) in Indonesia, Marcellino (2005) found that CBLT could not be implemented well because of several factors, one of which was an insufficient teachers' English competency to communicate and teach in English. Marcellino (2005) used survey, observational and interview data but, unfortunately, this study did not provide information about the number of teachers observed and interviewed or how the data was gathered and analysed.

Previous studies also suggest that Indonesian EFL teachers are challenged by their low English proficiency (Lengkanawati, 2005) and tendency to use their first language (Bahasa Indonesia) to communicate in academic forums (Lie, 2007) and in the classrooms (Marcellino, 2005). Indeed, very little is known about how Indonesian EFL teachers perceive and evaluate their own English proficiency.

Schmid and Mehotcheva (2012) argue that external factors, such as language contact and language use, affect the acquisition and attrition of the foreign language. Therefore, in countries where English is not used outside of the EFL classroom, such as Indonesia, the English language proficiency of EFL teachers may decrease over time, unless they have regular opportunities for meaning-focused input and output, at an appropriate level. Therefore, investigating L2 estimated and perceived proficiency of Indonesian EFL teachers and the factors that support or inhibit their L2 language maintenance is imperative.

However, very little is known about Indonesian EFL teachers' estimated and perceived proficiency and the factors that support or inhibit their effort to maintain their target language proficiency. Much of the research on Indonesian EFL teachers' proficiency has been limited to the teachers' perceived and observed English language proficiency (Lengkanawati, 2005; Lie, 2007; Marcellino, 2005). These studies also showed some interesting data in which the Indonesian teachers have rather unfavourable language proficiency because in a context where English is mostly confined to the classrooms or academic forums, as it is in Indonesia, teachers appear to lose their language proficiency gradually. Thus, it is necessary to investigate the estimated and perceived English language proficiency of Indonesian EFL teachers and the factors, which support or inhibit the ability of these teachers to maintain their target language proficiency after their formal teaching training.

Previous studies have also indicated that the factors that can both support and inhibit the teachers' effort to maintain their target language proficiency include the learners' proficiency levels and their personal efforts to improve their professionalism after teaching (Richards, 2017). Widodo and Riandi (2013) found that Indonesian teachers' motivation for continued learning might thrive or be impeded by the availability of support from their institutions and by the implementation of policies for professional development (PD). They also recommend initiatives for $\mathrm{PD}$ that include incentives such as promotion, introducing e-learning, and developing inhouse, in-service programmes for teachers which aim for collaboration and autonomy for these professionals. While previous studies have focused on curriculum and teaching development, the present study investigates EFL teachers' English language proficiency and PD approaches that facilitate its maintenance and development.

In the present study, we operationalised estimated proficiency as the EFL teachers' results on three tests measuring their target language vocabulary knowledge, and reading and writing ability. We operationalised perceived L2 proficiency as belief that the teachers had about their vocabulary knowledge, and reading and writing ability. We have included vocabulary knowledge in these measures because it plays a critical role in language comprehension and production (Laufer, 1997; Laufer \& Ravenhorst-Kalovski, 2010; Lee \& Schallert, 1997). While we agree to Renandya et al.'s idea (2018) to reassess the use of TOEFL or IELTS as a measure of one's general proficiency of English in government institutions, educational establishments and in English Language teacher educations institutions, we used those kinds of standardized tests in the present study because Indonesia has not developed a more relevant test that include General Proficiency and Pedagogical Language Proficiency as they suggest.

\section{METHOD}

This study aimed to investigate a key overarching question, whether EFL teachers are able to maintain their English proficiency overtime, by looking at three aspects: (1) the EFL teachers' estimated English 
language proficiency, (2) the possibility for EFL teachers to maintain their English language proficiency after receiving their formal teaching training, and (3) the EFL teachers' perceived English language proficiency, and what supports or inhibits its maintenance. A mixedmethods approach was used to investigate the questions in this study. This method was used because it is believed to provide more robust, detailed, and contextualized studies rather than using only one approach (Creswell, Clark, Gutman, \& Hanson, 2003, p. 165). The quantitative data were gathered from the questionnaire and the L2 proficiency tests. The qualitative data were gathered from the interviews with the teachers. The study was administered from June 2013 to September 2014, conducted in Indonesia and New Zealand.

\section{Respondents}

The study's participants were selected from the accessible population of high school and pre-service EFL teachers in Malang District, East Java Province, Indonesia. Convenience or opportunity sampling was used in the present study. This non-probability sampling refers to the main important criterion of sample selection is the convenience to and resources of the researchers (Dörnyei \& Csizér, 2012, p. 81). In other words, the pre-service and in-service teachers participated voluntarily in the present study were selected because they were accessible and had some characteristics that served the purpose of the investigation such as a wide range of service years (from 0 to 32 years of teaching experience) needed to understand the correlation between their years of service and English language proficiency. Altogether, 68 respondents, 60 in-service teachers and 8 pre-service teachers, showed up in the teacher meetings and were willing to fill the questionnaire. However, only 62 participants (55 in-service teachers and 8 pre-service teachers) showed up in the follow-up meetings and did the three language tests. While it is important to know the variant between the two groups of teachers (in the questionnaire and English proficiency test sessions), it was not possible to differentiate who participated in both sessions and who participated in one of them. This issue was caused by the fact that the questionnaire used an anonymous approach and the attendance record from the same session was managed by one of the three teacher coordinators and was not an accurate document to be used as a reference.

Despite the total number of the participants, nine teachers agreed to be interviewed by the researchers. Three teachers were fresh graduate and they represented the pre-service teachers with less than 3 years of teaching experience. Three teachers represented in-service teachers whose years of service range from 3 to 14 years and the other three teachers represented those who had been teaching for more than 15 years. Three teacher coordinators who supervised in senior high schools, junior high schools and vocational high schools in the Malang district acted as mediators for recruitment in this study. These three teacher coordinators played significant roles because they were responsible for mobilizing the teachers to the Musyawarah Guru Mata Pelajaran (MGMP) or School-Cluster Subject Teacher Working Group meetings. These meetings became the vehicles that we used to meet the participants and administer the study.

\section{Instruments}

Three main instruments were used in the study. The first instruments were three target language tests that were used to obtain the data on the EFL teachers' English vocabulary levels, reading proficiency, and writing proficiency. The second instrument was the questionnaire and the third instrument was the interview guide.

The three target language tests were VLT (Vocabulary Levels Test), IELTS Academic Reading Test, and IELTS Writing Test. The VLT was a monolingual English-English (Version B from Schmitt et al., 2001). The test consists of five levels (2000, 3000, 5000, Academic Word, and 10,000 levels representing high frequency, mid-frequency, and low frequency words respectively). Each level tests the testtaker's ability to recognize the synonyms of 30 words (see https://www.lextutor.ca/tests/vlt2/?mode=test). The VLT was used because of several reasons such as vocabulary knowledge measurement (Nation, 1983; Schmitt, Schmitt, \& Clapham, 2001) based on the Academic Word List (AWL) (Coxhead, 2000), a validated test (Beglar \& Hunt, 1999; Schmitt et al., 2001) widely used to measure written receptive vocabulary knowledge (Cobb, 1999; Webb \& Chang, 2012), and vocabulary profiles of the participating teachers. The second test was IELTS Academic Reading Test. An IELTS score of 5.5 is the required proficiency baseline for the ELT teacher training graduates in Indonesia (Faculty of Letters, 2017, p. 22). The third test was an IELTS Writing Test in the academic version (Task 2) used to assess the writing proficiency of the EFL teachers. The topics were taken from the online IELTS writing topic specimens and were available online (http://www.goodluckielts.com/IELTS-essay-topics.html). The writing prompts used in the writing test of the present study were from the academic version of the IELTS because the study aims to evaluate teachers' writing proficiency in academic (teaching) contexts. The participants had to write at least 250 words to express their ideas in argumentative essays on given topics in 40 minutes.

The next instrument was the questionnaire. The questionnaire used in this study was developed by modifying a survey designed by Fraga-Cañadas (2010) to investigate high school native and non-native Spanish teachers' beliefs about their language teaching and learning practice. The questions relevant to the teachers' L2 proficiency are: (1) Since you have received your teaching qualification how would you describe your overall English proficiency? (2) At present, how would you describe your lexical, reading and writing 
proficiency? (3) Please indicate to what extent you disagree or agree with the following statements: I frequently seek opportunities to write and read in English; and (4) Thinking only outside the school settings, how often have you had time to engage in the following activities (reading English materials and writing in English) during the last three school years (since July 2010).

The third instrument was the interview guide. The purpose of the interviews with nine teachers was to better understand teachers' perceived target language proficiency and factors affecting it. The interviews were carried out individually, using long-distance phone calls via Skype to home or mobile phones, or via Facebook video chat since the respondents were based in Indoneisa and the researchers were based overseas. The interviews were mostly carried out in L1, Bahasa Indonesia, to ensure that the EFL teachers understood the questions and were comfortable when answering them.

\section{Procedures of collecting the data}

To obtain the data for the study, some research procedures were taken. The permission from the District Ministry of Education in Malang, East Java, Indonesia, was granted before contacting the three teacher coordinators from the three school levels: junior high, senior high, and vocational high schools. One of the researchers came to the teacher meetings in three different schools, the junior high school teacher meeting, the senior high school teacher meeting, and the vocational school teacher meeting. After gaining consents from the participating teachers, she handed out the questionnaire and asked the teachers to fill out the questionaire. Later, when the teachers had another teacher meeting, they were asked to do the three English language tests. The interviews were done on the later stage of the study to those who agreed to participate in the interview stage (as indicated in their consent forms).

\section{Data analysis}

Two types of data were gathered from the three data collection methods. The quantitative data of the EFL teachers English proficiency tests' results were analyzed using Statistical Package for the Social Sciences (SPSS) 20 (IBM Corp, 2011). In the VLT test, one point was given to each correct match of a word and its definition, maximum 30 points per frequency level (Nation, 1983;
Schmitt et al., 2001). In the reading test, one point was given for each correct answer and the scoring followed the standard IELTS marking approach, maximum 40 points

(see http://www.examenglish.com/IELTS/IELTS_Band_Sco res.html). The writing test was scored by two raters (high-proficiency EFL speakers) following a standard approach

(https://takeielts.britishcouncil.org/sites/default/files/201 8-01/IELTS_task_2_Writing_band_descriptors.pdf ). With 62 participants, Rater $1(\mathrm{M}=5.169, \mathrm{SD}=1.130)$ and Rater $2(\mathrm{M}=5.349, \mathrm{SD}=.973)$, the Cronbach's Alpha was .852 confirming good interrater reliability (as Cronbach's Alpha of .700 is considered acceptable).

To investigate the relationship between estimated proficiency and length of teaching service, a one-tailed Pearson correlation coefficient $(r)$ was used. The Pearson product-moment correlation was used to describe the strength and direction of this relationship (Pallant, 2011). The one-tailed statistic was used because a negative correlation between the length of service and proficiency was hypothesized.

Finally, thematic analysis (TA) was used to analyze the interview data with the nine EFL teachers because this analysis is 'for identifying, analysing and reporting patterns (themes) within data' (Braun \& Clarke, 2006, p. 79). TA as a method of data analysis is accessible because it allows me to code and analyse qualitative data systematically and link the codes to broader theoretical or conceptual issues (Braun \& Clarke, 2012: 58).

\section{FINDINGS AND DISCUSSION \\ The EFL teachers' estimated target language proficiency}

The VLT results $(\mathrm{N}=62)$ showed a wide range of scores (see Table 1) from very low to very high, at all levels of the test. A VLT score of 26 indicates mastery at the corresponding word frequency level (Schmitt et al., 2001). The mean of 27.40 shows that, on average, the EFL teachers had mastered vocabulary at the 2000-word level. At the 3000-word level (24.42) and the AWL level (23.37), the mean score was also reasonably high, but did not reach mastery. The teachers did not achieve mastery of the mid-frequency (5000-word list) (19.74) or low frequency $(10,000$-word list) (6.95) vocabulary.

Table 1. English proficiency test results

\begin{tabular}{lrcrc}
\hline & Minimum & Maximum & Mean & Std. Deviation \\
\hline VLT Levels & \multicolumn{5}{c}{} \\
\hline 2000 & 13 & 30 & 27.40 & 3.56 \\
3000 & 8 & 30 & 24.42 & 5.07 \\
5000 & 3 & 29 & 19.74 & 6.32 \\
10000 & 0 & 27 & 6.95 & 6.54 \\
AWL & 0 & 30 & 23.37 & 7.75 \\
\hline IELTS Tests & & & & \\
\hline Reading & 1.0 & 8.5 & 4.82 & 1.42 \\
Writing & 2.5 & 7.5 & 5.36 & .97 \\
\hline
\end{tabular}


Table 1 also shows the reading and writing test results. On the reading test, the teachers' mean score was 4.82 on the IELTS scale, with 40 out of the 62 teachers scoring lower than or equal to IELTS band 5 . The teachers' mean writing score was 5.36. That said, 23 teachers $(37 \%)$ scored below 5.5 on the IELTS scale. This result confirms that the teachers' reading mastery was lower than the expected baseline and their writing ability was only slightly below the required baseline of 5.5 IELTS for English language teachers in Indonesia. Taken together, the estimated proficiency of the EFL teachers in this study was below the required baseline (Faculty of Letters, 2017, p. 22). This situation was not unexpected and suggests that the EFL teachers' knowledge of the mid-frequency vocabulary, academic words and low frequency words was somewhat substandard. The fact that EFL teachers mastered the first two thousand words somewhat resonances the findings in the studies administered by Nurweni and Read (1999) and Webb and Chang (2012). Their studies showed that learners did not successfully master the first two thousands words of English, even after some years of study. The present study reveals that the EFL teachers' vocabulary mastery was sub-standard even after some years of teaching. Similar to the results of the vocabulary test, the reading results show that, in general, the teachers' proficiency was lower than the expected baseline and that their writing ability was only slightly below the required baseline of 5.5 IELTS
(Faculty of Letters, 2017, p.22). These results are consistent with other previous studies which found that EFL teachers were challenged by their low English proficiency and they tended to use their first language (Bahasa Indonesia) to communicate in academic forums (Lie, 2007) and to communicate with their students in the classrooms (Marcellino, 2005). Because EFL teachers have to use English to communicate with their students and model language use for their students (Renandya et al., 2018 \& Richards, 2017), we believe that EFL teacher English language proficiency is a core part of their professionalism. Reflecting upon the results of the proficiency tests, greater efforts are needed to ensure that professional development (PD) of the EFL teachers in Indonesia needs to be adjusted to better help them achieve and maintain the required level of professionalism in terms of their L2 proficiency.

\section{EFL teachers' English language proficiency appears to diminish over time}

Inferential statistics from the VLT test results show no significant correlations at the 2000, 3000 and 10000 levels and a weak trend in the predicted direction at the 5000 level $(r=-.168, \mathrm{p}=.095)$. A reliable negative correlation was observed between the teachers' years of service and their AWL level scores (see Table 2), showing that longer-serving teachers knew fewer academic words.

Table 2. Pearson correlations of length of service and vocabulary, reading and writing $(\mathrm{N}=62)$

\begin{tabular}{|c|c|c|c|c|c|c|c|c|}
\hline & & $\begin{array}{l}\text { 2000 } \\
\text { WL }\end{array}$ & $\begin{array}{l}\text { 3000 } \\
\text { WL }\end{array}$ & $\begin{array}{c}5000 \\
\text { WL }\end{array}$ & $\begin{array}{c}10000 \\
\text { WL }\end{array}$ & AWL & Reading & Writing \\
\hline \multirow{2}{*}{ Length of Service } & Pearson Correlation & -.086 & -.160 & -.168 & -.127 & $-.30 * *$ & $-.34 * *$ & $-.37 * *$ \\
\hline & Sig. (1-tailed) & .253 & .107 & .095 & .162 & .009 & .003 & .002 \\
\hline
\end{tabular}

** Correlation is significant at the 0.01 level (1-tailed)

There was a medium negative correlation between the teachers' length of service and their reading and writing proficiency (see Table 2). Overall, these results show a medium negative relationship between years of teaching and target language proficiency. The findings indicate that a minimum threshold level of professionalism expected of all school teachers was not maintained, with a decline in L2 proficiency observed over time. However, it is important to treat these findings with caution because of the rather restricted participant recruitment process. The negative correlation may be accounted for by considering the status and role of English in the Indonesia. According to Dardjowidjojo (2000), Jazadi (2000), and Lauder (2008), English is a foreign language in Indonesia and is one of compulsory subject in secondary high schools and tertiary education in Indonesia. This means that English is mostly confined inside the classrooms' walls and is rarely used outside the classrooms. Thus, we argue that if the EFL teachers do not maintain their English language proficiency after receiving their formal teaching training, their proficiency may diminish over time.

The results of the present study extend BardoviHarlig and Stringer's (2010) claim about the effect of the duration and nature of reduced input and use beyond high school students, missionary returnees, and federal employees whose jobs include the use of second language to in-service teachers of English as a foreign language in Indonesia. The present study (see Table 2) shows that in-service teachers with longer years of service tended to have lower academic vocabulary, reading proficiency and writing proficiency than those who have shorter years of service. The present study also shows that the pre-service teachers tended to have higher academic word knowledge, reading proficiency and writing proficiency than the in-service teachers. On the basis of this evidence, it seems fair to conclude that reduced target language input and use result in L2 attrition in EFL teachers.

The negative correlation between EFL teachers' years of service and their academic word knowledge and reading and writing proficiency also appear to validate the view that, for second/foreign language users, the issues of acquisition and attrition of the target language are multifaceted (Bardovi-Harlig \& Stringer, 2010; Schmid \& Mehotcheva, 2012). Schmid and Mehotcheva (2012) argue that second/foreign language users are challenged by factors that come from within 
the linguistic system and from the surrounding environment, as well as by internal factors within the second/foreign language users themselves. The analysis of the interview data shows that the teachers were challenged by a number of extra linguistic factors, such as the lack of time, excessive use of the L1, Bahasa Indonesia, and lack of exposure to the target language. Thus, the EFL teachers in the present study were challenged by some of the extra linguistic variables identified by Bardovi-Harlig and Stringer (2010) and Schmid and Mehotcheva's (2012). However, further studies are needed to fully consider the effect of external and internal factors on the foreign language attrition among EFL teachers in Indonesia.
EFL teachers' perceived English language proficiency, and factors that supports or inhibits its maintenance

Forty-one out of 68 teachers believed that their overall English proficiency improved over time (note: not all teachers answers all questions in the questionnaire). Only six teachers reported that they felt their overall English proficiency had declined since their graduation from college (See Figure 1).

Responding to questions related to their vocabulary knowledge, and reading and writing proficiency in English (Figure 2), the participants had more confidence in their reading ability $(72 \%)$ than in their writing ability $(38 \%)$ or their vocabulary mastery $(43 \%)$.

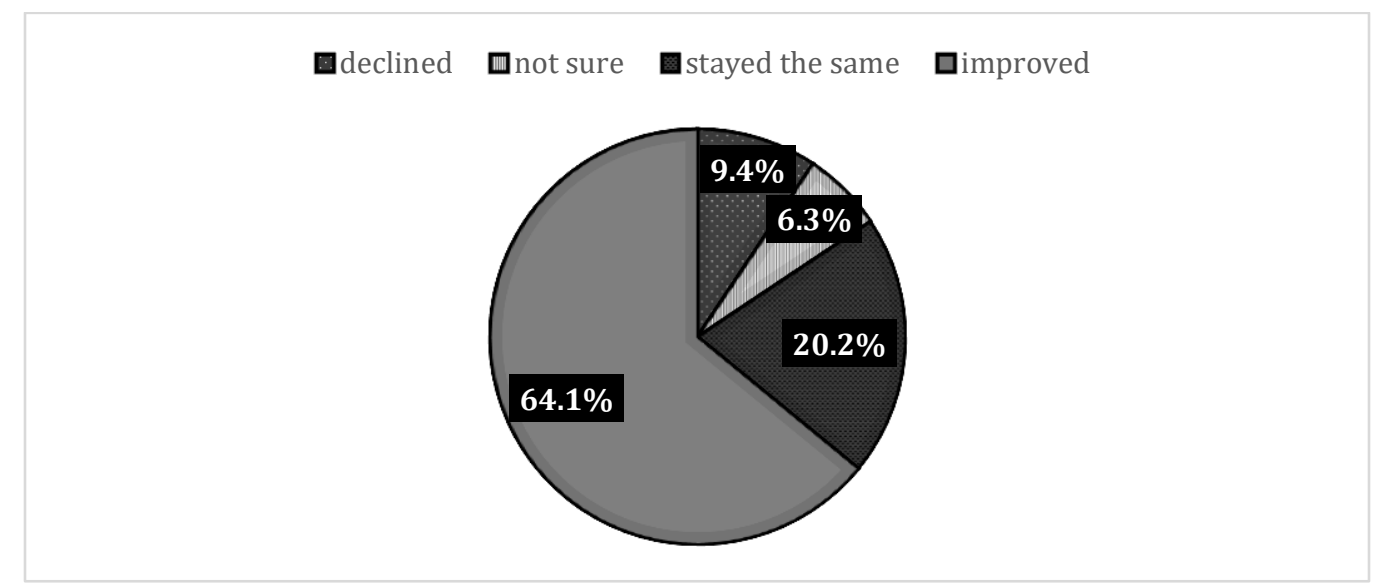

Figure 1. Self-reported data: Teachers' perceived ability to maintain English language proficiency

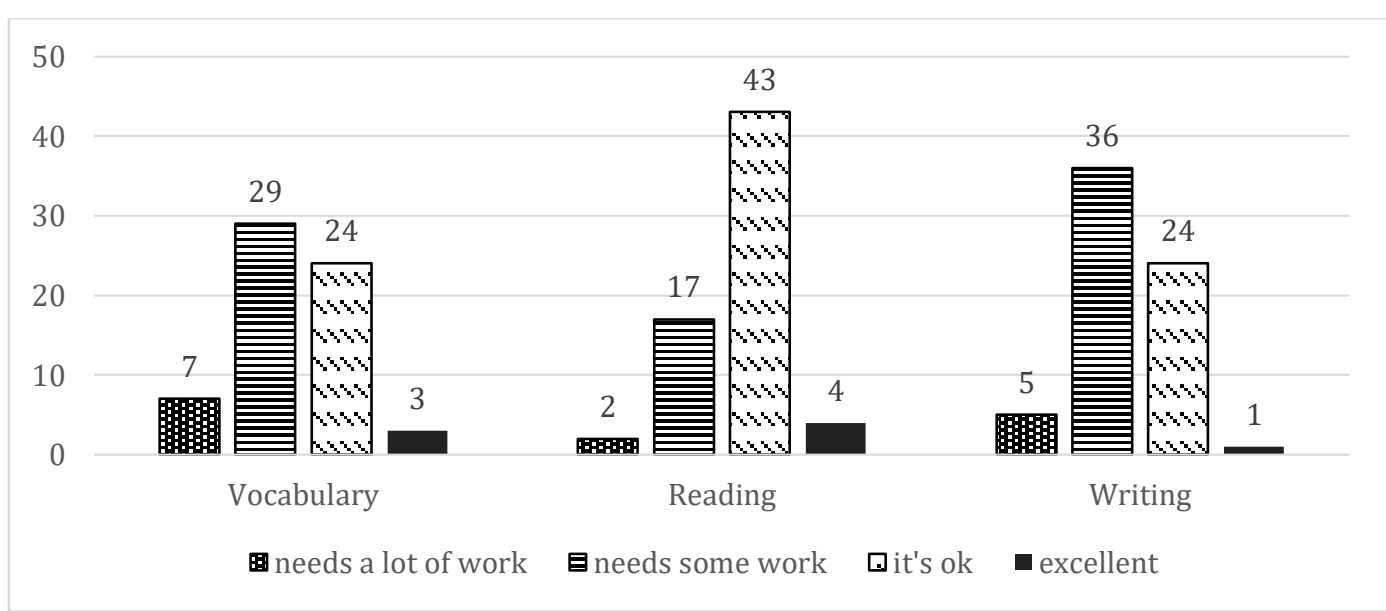

Figure 2. Self-report data: Teachers' perceived reading, writing and lexical proficiency

The reading bar chart in Figure 2 shows that a total of $47(71.21 \%)$ out of 68 teachers believed that their reading proficiency was fine, with four teachers $(6 \%)$ reporting that their reading skills were excellent. Nineteen teachers $(28.78 \%)$ perceived that their reading skills needed to be improved. The writing bar chart in Figure 2 also shows that $41(62.12 \%)$ out of 68 teachers thought that they had poor writing skills. Only one teacher $(1.5 \%)$ believed her writing skills were excellent.
Most teachers reported frequently seeking opportunities to read and write in English (see Figure 3). A total of $65(98.48 \%)$ teachers frequently looked for chances to read in English and a total of 59 (92.18\%) teachers frequently sought chances to write in English.

However, a different pattern emerged when participants responded to questions about their participation in specific target language activities in the previous three years (see Figure 4). Thirty-six EFL teachers $(56.25 \%$ of the respondents, i.e., only just over half of the teachers) stated that they read books in 
English to maintain their English proficiency and only twenty-five $(37.31 \%)$ frequently read English magazines. In relation to their writing practice, 23 teachers $(37.09 \%)$ used online text chat in English, 18 $(28.12 \%)$ wrote letters or emails in English, and only five $(8.06 \%)$ wrote blogs.

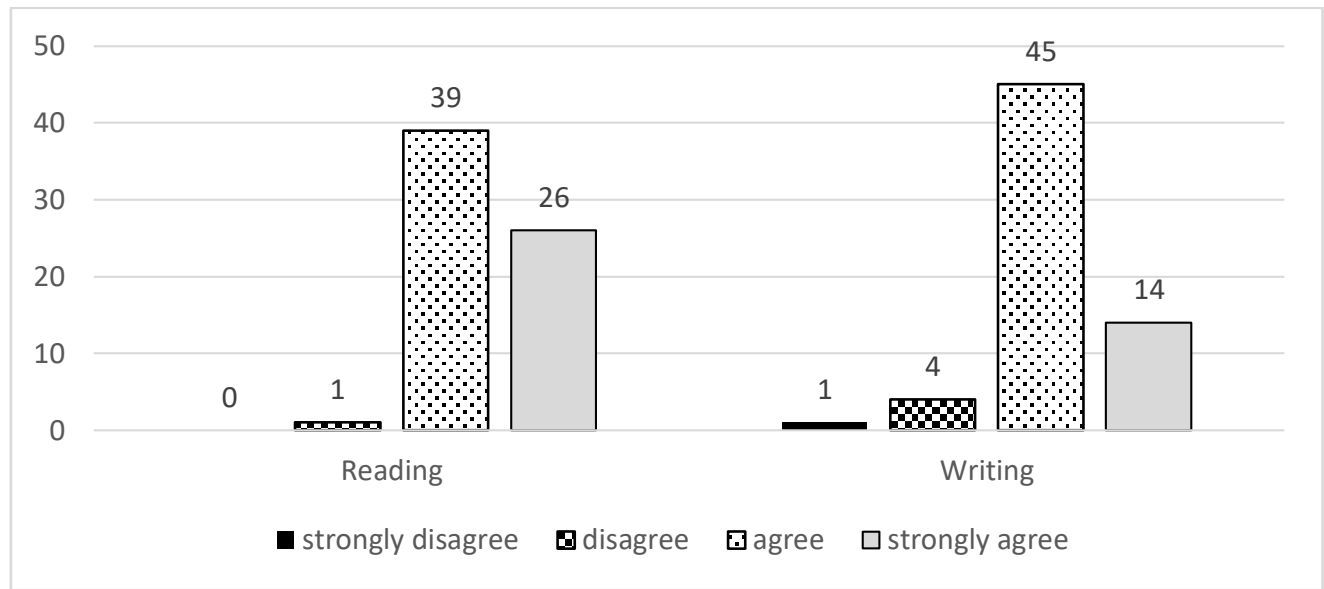

Figure 3. I frequently seek opportunities to read and write in English

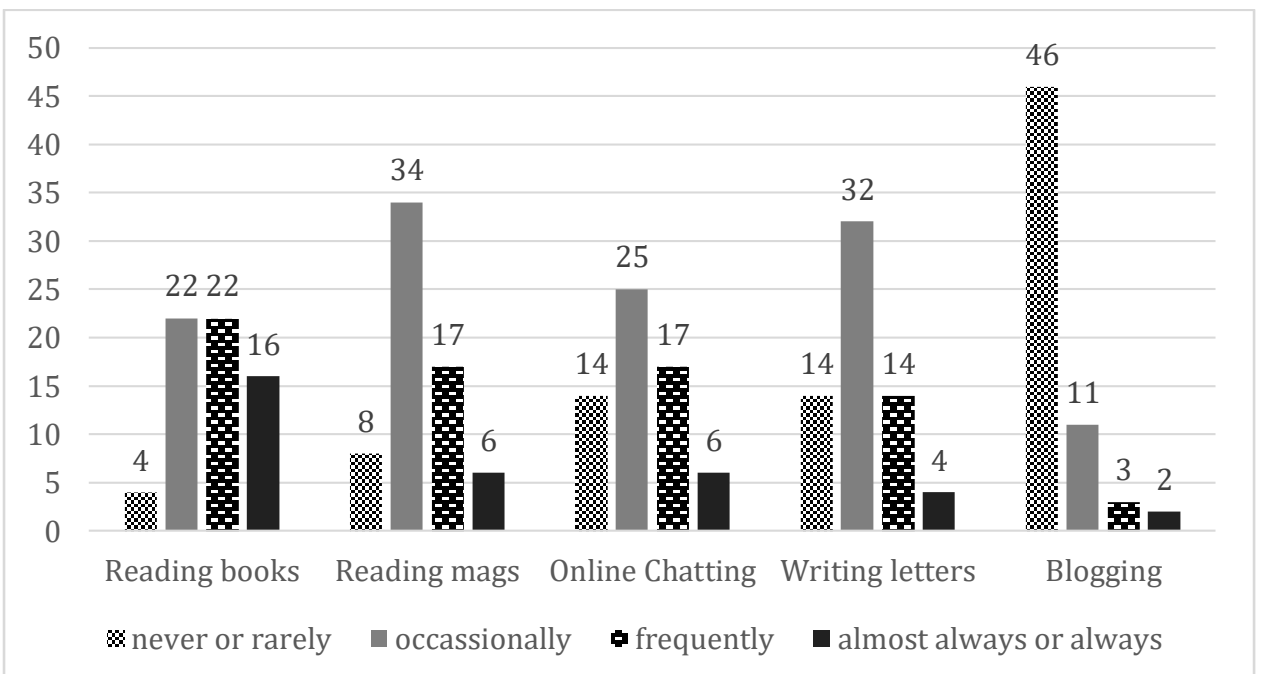

Figure 4. Thinking outside the school setting, how often have you had time to engage in the following activities during the last three school years (since July 2010)?

The follow-up interviews with the nine EFL teachers revealed four factors that were perceived as helpful in maintaining target language proficiency: sharing knowledge, participating in PD programmes, utilizing various media platforms, and reading and writing in English. The following three factors were seen as hindering teachers' ability to maintenance and improve their target language proficiency: a lack of time due to heavy teaching loads, the use of Bahasa Indonesia (L1) in class to help students understand the lessons, and a lack of exposure to English. We note also that school internal policy and funding decisions had an impact on EFL teachers' access to PD, as became apparent in the course of this study. Let us look at each of these impediments, in turn.

Time was a key barrier for the teachers in maintaining their English language proficiency. Five of the EFL teachers were clear that they just did not have time to read or write much in English. One junior high school teachers, Adya, explained the impact of the workload and the administrative duties on her ability to maintain her L2,

"That's the problem. I don't know if I am too naïve or what but in my school, teachers' duties are not only teaching their subject matters. Take me as an example, I am not only a subject matter teacher of English but also a supervisor for student intracurricular activities as well as English language laboratory manager. It means that the time I should use to improve my quality as an English teacher is taken by those administrative tasks. That's why there is no sufficient time left for me to read and write to friends or colleagues in English".

A second factor emerging from interviews was the use of the L1 in classrooms and in their daily lives, which impacts their exposure to the target language. 
The same junior high school teacher, Adya, described her experiences,

"To me, I think my English proficiency declined. It declined because when I am in the field, I didn't use English. My students rejected the idea of using it. They rejected because when they were in primary schools they were not accustomed to use it. They just can't. I had not used English from 2009 to 2013. I used Bahasa Indonesia in the classrooms and with friends. I felt ashamed of meeting my friends who also graduates from ELT programme because my using Bahasa Indonesia. I have forced myself to use English in the classrooms since 2013. I rarely read English literature too".

In a few cases, school principals only allowed one particular teacher to participate in the PD programme. Dada (a teacher coordinator) said:

“... For some schools, the policy of their principals in this event [TPD] is different from one to another. Some principals always appoint a particular person to attend the event. There was no chance for other teachers to attend the TPD programme".

This is very unfortunate because other English teachers in those schools might not have chances to learn from the programmes unless a sharing session was programmed following the event. With regards to what Dada stated, other teachers may need to request for special permission from the principals and spend their own fund to attend the TPD programmes. This idea can be seen from Rahman's (a senior high school teacher) statement. He outlined his frustrations and reasons for wanting to attend PD by saying,

“...I was not sent for the professional development program. I requested the principal to send me to the program. I don't want to teach only. I need to enhance my knowledge. I am not yet satisfied. I always want to participate in such programs".

In terms of policies for deciding on who might attend PD sessions, school principals might decide that only teachers who have achieved well or who are preferred by the principals could participate. The effect of funding and policy decisions is that only a few teachers would enjoy the privilege of attending PD sessions that might help them to maintain or improve their professionalism as English teachers. Two key issues became clear from the interviews. First, some teachers were interested in PD and nominated themselves for upcoming programs and second, issues of policy and funding in regard to PD for these teachers are persistent.

In summary, the estimated target language proficiency of the EFL teachers in this study is shown to be somewhat below the legislated baseline in writing and reading (see Table 3 ). The vocabulary results suggested that the teachers' lacked knowledge of midfrequency vocabulary, which is problematic because a vocabulary of around 8000 word-families for novels, newspapers and academic texts in English (Nation, 2006). These findings suggest that the proficiency of these EFL teachers in Indonesia appears to need improvement, which is in line with findings reported by Lengkanawati (2005).

Table 3. EFL teachers' perceived and actual proficiency

\begin{tabular}{lll}
\hline Vocabulary & \multicolumn{1}{c}{$\begin{array}{c}\text { Perceived proficiency } \\
\text { (questionnaire) }\end{array}$} & \multicolumn{1}{c}{$\begin{array}{c}\text { Actual proficiency } \\
\text { (L2 proficiency tests) }\end{array}$} \\
Reading & Mostly desired & $\begin{array}{l}\text { Good at 2K, acceptable at 3K and AWL, weak at 5K and very } \\
\text { poor at 10K levels }\end{array}$ \\
Writing & Somewhat lower than desired & $\begin{array}{l}\text { The mean score is between 4 and 5 on the IELTS band-scale } \\
\text { (M=4.82), i.e. below the threshold of 5.5 }\end{array}$ \\
$\begin{array}{l}\text { Overall proficiency } 5 \text { and } 6 \text { on the IELTS band-scale (M=5.36), i.e. close } \\
\text { to the threshold of 5.5 } \\
\text { time }\end{array}$ & $\begin{array}{l}\text { Improved since graduated from } \\
\text { Bachelor of ELT }(64.1 \%)\end{array}$ & $\begin{array}{l}\text { Lower than the expected standards; and there's a tendency for } \\
\text { proficiency to be lower, across all measures, for the longer } \\
\text { serving teachers. }\end{array}$ \\
\hline
\end{tabular}

The results of this study also showed that there were some discrepancies between the EFL teachers' perceived and actual English language proficiency, as can be seen in Table 3. The participants tended to believe that they had lexical proficiency that was lower than desired. The results of the VLT showed that they mastered the high-frequency vocabulary and were close to mastery of the 3,000 word-level and academic vocabulary, but did not master mid-frequency (or lowfrequency) vocabulary. Overall, participants' judgements of their vocabulary mastery were aligned with the tests. A possible explanation for the EFL teachers' solid high-frequency vocabulary but low mid, high and academic word levels and low reading proficiency is the possible correlation between vocabulary knowledge and reading proficiency (Laufer, 1997, 2012; Laufer \& Ravenhorst-Kalovski, 2010; Lee \& Schallert, 1997). The finding that the EFL teachers did not do well on the reading comprehension test suggests that they may not have been able to access their knowledge of mid-frequency and academic vocabulary. This because a high proportion of unknown words in a text makes it higher probable that the reader misses or misinterprets contextual clues needed to 
answer comprehension questions (Laufer \& RavenhorstKalovski, 2010, p. 31).

However, the teachers' self-assessment of the reading and writing skills were less accurate. They were mostly not satisfied with their writing ability in English, but the writing test showed scores that were meeting the baseline proficiency requirement of 5.5 IELTS. On the other hand, the EFL teachers showed that they had basic English writing skills, even though their average scores on the writing test were slightly lower than the set baseline of 5.5 IELTS. A possible explanation why teachers' writing results were closer to the standard than their reading results is topic familiarity, as the EFL teachers are likely to be mostly familiar with the topic given to them as a writing prompt (i.e. retirement age). Furthermore, the knowledge of basic English vocabulary (the mastery of the first 2000 words and moderate knowledge at the 3000 word and academic word level) was sufficient to write an essay on a familiar topic.

In contrast, the teachers were satisfied with their reading proficiency, but the reading test showed an average reading score lower than 5.5 IELTS. This difference may be due to the fact that the frequency of using the target language outside of the classroom was insufficient to maintain their baseline target language proficiency. The results suggest that, while the EFL teachers taught English as a foreign language in Indonesian high schools, they experienced a period of declining use. The EFL teachers had used English to communicate with their teacher trainers and classmates during their initial teacher education. However, once they graduated and started teaching in an EFL teaching context, most of their students and colleagues did not speak English. Thus, they could not use English frequently to communicate with others. These results support Schmid's (2011) conclusion that the decline of use due to changes in one's linguistic environment and language habits may negatively affect language proficiency. The results further confirm the association between second/foreign language attrition and external factors, such as contact with and/or use of the language (Bardovi-Harlig \& Stringer, 2010; Schmid \& Mehotcheva, 2012). Bardovi-Harlig and Stringer (2010) argue that decreased opportunities to communicate using the target language are associated with second language attrition. They claim that the time second language learners spend away from using the target language is the period of fewer chances in language use. In addition, Schmid and Mehotcheva (2012) maintain that once a foreign language user is removed from their supportive environment, there is a greater possibility for her not to be able to retain the language.

Therefore, the present study suggests that the EFL teachers may not have a very good representation of their own ability in the English. Of concern is also the teachers' belief that their overall English proficiency continues to improve over time, while the analysis showed a negative correlation between years of service and proficiency. This suggests that EFL teachers experienced a period of declining use and need better training and support in evaluating their professional competences..

The lower test results on reading, writing and academic vocabulary for longer-serving teachers may result from external linguistic factors, such as insufficient contact with and use of the target language (Schmid \& Mehotcheva, 2012, p. 15), which is particularly problematic in the context of EFL teachers in Indonesia. When EFL teachers leave university, they are removed from a supportive language learning environment into an environment where English is rarely used at the level needed to maintain their proficiency in English. Teachers rarely use English inclass (Marcellino, 2005) or out-of-class (Lie, 2007). While there are plenty of online tools and platforms that can potentially be used to share ideas or access information, it appears that EFL teachers in this study based in Indonesia do not use them to maintain and improve their target language proficiency. This lack of exposure to English and periods of declined use may have caused language attrition (Bardovi-Harlig \& Stringer, 2010). In addition, Richards (2017, p. 13) states that "EFL teachers' use of language while teaching is not only influenced by his or her own language proficiency and discourse skills but will also be impacted by the learners' proficiency level and their participation in PD activities." The finding of the present study lends support to Richards (2017) where EFL teachers' language skills that were somewhat lower than desired had negatively affected their use of language when teaching their students.

\section{CONCLUSION}

This study suggests that although, on average, the EFL teachers in Malang District, East Java Province, Indonesia, demonstrate mastery of high-frequency vocabulary and close to adequate writing ability in English, their estimated knowledge of mid-frequency vocabulary and reading proficiency require support. Furthermore, the English language proficiency level achieved when EFL teachers graduated from university shows evidence of attrition. Deliberate measures are, therefore, needed to support target language maintenance of EFL teachers, and professional development (PD) approaches that align institutional and individual goals could be some of the measures.

The findings of the study have implications for teachers, policy makers, teacher educators and principals. The most important point to make is that the proficiency of English language teachers needs careful and targeted support. A combination of institutional and individual teacher development programmes is crucial to maintaining and improving EFL teachers' L2 proficiency (Farrell, 2015; Harvey et al., 2010; Renandya et al., 2018; Richards et al., 2013; Richards, 2017). Firstly, teacher proficiency development needs to be supported by institutions and government policy. Teachers with heavy workloads and limited chances to 
use English require time and opportunity to focus on their own language learning and maintenance needs. Furthermore, the high variability in target language proficiency (as shown in our study) means that a range of approaches and options is needed for teachers at different times of their professional lives. Schools and teachers could work collaboratively to set goals for and include language proficiency into their PD activities. Simple ideas such as vocabulary cards for learning (Nation \& Yamamoto, 2012), blogs for practising writing (Campbell, 2003) where access to technology is readily available or in-house paper-based newletters where technology is limited, and websites for practising reading (such as the Extensive Reading Foundation website, available at http://erfoundation.org/wordpress/) can be instituted at a very low cost. Any PD programmes like these would need to be regularly evaluated and adjusted, for an ongoing improvement (Richards \& Farrell, 2005, p. 20).

Indeed, at the institutional level, needs analyses such as the one carried out by Widodo and Riandi (2013) and environmental analyses are essential in designing programs for maintaining and developing teacher professional competency. At the individual level, self-motivation to continue learning is crucial for English language teachers. At the national level, selfmotivation to benchmark their skills against the ASEAN EFL teachers' standard is also imperative for English teachers (Widiati \& Hayati, 2015). Learning from other ASEAN countries, such as Vietnam, we could see that it progressively works to improve the quality of its English language teachers. We note that the Vietnamese Standardized Test of English Proficiency (VSTEP) which is required for graduation is one approach to providing impetus for teachers to work on their English language proficiency (Dudzik \& Nguyen, 2015). It is beyond the scope of the present study to consider such a testing project.

We acknowledge a number of limitations of the present study. There was uneven participation in the two sets of data gathering (proficiency test and questionnaire), which makes it difficult to fully match them. Also, convenience sampling was used to recruit the participants, affecting the generalizability of the findings to populations with different characteristics and teaching and learning experiences. Finally, the present study only investigated the teachers' reading and writing proficiency and vocabulary knowledge. Listening and speaking skills were not tested. The reading and writing test results may not be representative of the accurate IELTS levels, because they were marked by non-IELTS trained markers.

Future studies should include larger populations in Indonesia or other EFL contexts with a more robust sampling procedure and include listening and speaking measures. Newer vocabulary tests such as Webb, Sasao, and Balance (2017, p. 54-55) could be used in place of the VLT because of three reasons. First, the inclusion of 1000 word levels allows teachers and researchers to measure knowledge of the vocabulary that likely has the greatest impact on a learner's ability to communicate in English. Second, the items from the new forms of the VLT were sourced from Nation's (2012) BNC/COCA word frequency lists that were designed to reflect current English in the United Kingdom and the United States. Thus, the test should provide a reasonable representation of the likelihood that vocabulary will be encountered in these contexts, as well as within a large proportion of language learning materials. Third, the addition of 4000 word levels allows the test to better reveal gaps in lexical knowledge than in the earlier versions of the test. As indicated by Renandya et al. (2018) and Elder and Kim (2013), to have a more comprehensive and reliable results of EFL teachers' English proficiency, the design of the future test should also consider the assessment of not only the teachers' general proficiency in English but also their pedagogical language proficiency. Researchers could also investigate what variables affect EFL teachers' language attrition in non-English speaking countries, other than low levels of input and use of the target language.

In conclusion, this study set out to argue that very little is known about Indonesian EFL teachers' estimated and perceived proficiency and the factors that support or inhibit their effort to maintain their target language proficiency. The findings of the present study provide a more comprehensive results of the EFL teachers' estimated and perceived proficiency as well as the factors that support or inhibit their L2 maintenance than the previous relevant studies. However, we understand that improving general proficiency of English is not sufficient if these EFL teachers want to be able to teach effectively and efficiently in English. Thus, individual and institutional efforts have to be garnered to arrive at the expected goals.

\section{ACKNOWLEDGEMENTS}

This study was funded by the Directorate of Higher Education of Indonesia (DIKTI) through the Beasiswa Pendidikan Luar Negeri (BPLN) from 2012 to 2015 and Victoria University of Wellington (VUW), New Zealand through the Victoria Doctoral Submission Scholarship in 2016. We also wish to acknowledge the support and participation of the teachers and schools.

\section{REFERENCES}

Bardovi-Harlig, K., \& Stringer, D. (2010). Variables in second language attrition: Advancing the state of the art. Studies in Second Language Acquisition, 32(1), 1-45. doi: 10.1017/S0272263109990246

Beglar, D., \& Hunt, A. (1999). Revising and validating the 2000 Word level and university word level vocabulary tests. Language Testing, 16(2), 131162. doi: 10.1177/026553229901600202.

Braun, V. \& Clarke, V. (2006). Using thematic analysis in psychology. Qualitative Research in Psychology, 3(2), 77-101. doi: 10.1191/1478088706qp063oa. 
Braun, V. \& Clarke, V. (2012). Thematic analysis. In APA handbook of research methods in psychology (Vol. 2, pp. 57-71), H. Cooper (Editor-in-Chief) Research designs: Quantitative, qualitative, neuropsychological, and biological. Washington, DC, US: American Psychological Association.

Cambridge IELTS 6. (2007). In Examination papers from University of Cambridge ESOL examinations: English for speakers of other languages (p. 176). Cambridge, UK: Cambridge University Press.

Campbell, A. P. (2003). Weblogs for use with ESL classes. The Internet TESL Journal, IX(2).

Retrieved from

http://iteslj.org/Techniques/CampbellWeblogs.html

Cobb, T. (1999). Breadth and depth of lexical acquisition with hands-on concordancing. Computer Assisted Language Learning, 12(4), 345-360.

Coxhead, A. (2000). A new Academic Word List. TESOL Quarterly, 34(2), 213-238. doi: $10.2307 / 3587951$.

Creswell, J. W., Plano Clark, V. L., Gutmann, M. L., \& Hanson, W. E. (2003). An expanded typology for classifying mixed methods research into designs. In A. Tashakkori \& C. Teddlie (Eds.), Handbook of mixed mehtods in social and behavioral research (pp. 209-240). Thousand Oaks, CA: SAGE.

Dardjowidjojo, S. (2000). English teaching in Indonesia. EA Journal, 18(1), 22-30.

Dörnyei, Z., \& Csizér, K. ( 2012). How to design and analyze surveys in second language acquisition research. In A. Mackey \& S. Gass (Eds.), Research methods in second language acquisition: A practical guide (pp. 74-94). Malden, MA: WileyBlackwell.

Dudzik, D. L., \& Nguyen, Q. T. N. (2015). Vietnam: Building English competency in preparation for ASEAN 2015. In S. Richmond \& K. Kimura (Eds.), ASEAN integration and the role of English language teaching (pp. 41-71). Phnom Penh, Cambodia: IDP Education (Cambodia).

Elder, C., \& Kim, S. H. O. (2013). Assessing teachers' language proficiency. In The Companion to language assessment. John Wiley \& Sons, Inc. Retrieved from http://onlinelibrary.wiley.com. doi: 10.1002/9781118411360.wbcla138/abstract

Faculty of Letters. (2017). Catalogue of Department of English 2017. Malang, Indonesia: Faculty of Letters, Universitas Negeri Malang.

Farrell, T. S. C. (Ed.). (2015). International perspectives on English language teacher education: Innovations from the field. Hampshire, England: Palgrave Macmillan.

Fraga-Cañadas, C. P. (2010). Beyond the classroom: Maintaining and improving teachers' language proficiency. Foreign Language Annals, 43(3), 395-421. doi: 10.1111/j.1944-9720.2010.01090.x
Hamid, M. O., \& Nguyen, H. T. M. (2016). Globalization, English language policy, and teacher agency: Focus on Asia. The International Education Journal: Comparative Perspectives, 15(1), 26-44.

Harvey, S., Conway, C., Richards, H., \& Roskvist, A. (2010). A report to the Ministry of Education: Evaluation of Teacher Professional Development Languages(TPDL)in years 7-10 and the impact on language learning opportunities and outcomes for students (p. 123). Wellington, New Zealand: Ministry of Education.

IBM Corp. (2011). IBM SPSS Statistics for Windows (Version 20.0) [IBM SPSS Statistics for Windows, Version 20.0]. Armonk, NY.

IELTS: Test Takers Home Page. (n.d.). Retrieved February 4, 2014, from http://www.ielts.org/test_takers_information.aspx

Jazadi, I. (2000). Constraints and resources for applying communicative approaches in Indonesia. $E A$ Journal, 18(1), 31-40.

Lauder, A. (2008). The status and function of English in Indonesia: A review of key factors. Makara, 12(1), 9-20.

Laufer, B. (1997). The lexical plight in second language reading: Words you don't know, words you think you know and words you can't guess. In J. Coady, \& T. Huckin (Eds.), Second language vocabulary acquisition: A rationale for pedagogy (pp. 20-34). Cambridge: Cambridge University Press.

Laufer, B., \& Ravenhorst-Kalovski, G. C. (2010). Lexical threshold revisited: Lexical text coverage, learners' vocabulary size and reading comprehension. Reading in a Foreign Language, 22(1), 15-30.

Lee, J.-W., \& Schallert, D. L. (1997). The relative contribution of L2 language proficiency and L1 reading ability to $L 2$ reading performance: A test of the threshold hypothesis in an EFL context. TESOL Quarterly, 31(4), 713-739. doi: $10.2307 / 3587757$

Lengkanawati, N. S. (2005). EFL teachers' competence in the context of English curriculum 2004: Implications for EFL teacher education. TEFLIN Journal: A Publication on the Teaching and Learning of English, 16(1), 79-92.

Li, M., \& Baldauf, R. (2011). Beyond the curriculum: A Chinese Example of issues constraining effective English language teaching. TESOL Quarterly, 45(4), 793-803.

Lie, A. (2007). Education policy and EFL curriculum in Indonesia: Between the commitment to competence and the quest for higher test scores. TEFLIN Journal: A Publication on the Teaching and Learning of English, 18(1), 1-13.

Marcellino, M. (2005). Competency-based language instruction in speaking classes: Its theory and implementation in Indonesian contexts. Indonesian Journal of English Language Teaching, 1(1), 3344. 
Mori, S., Ming, T. S., Nor, N. F. M., Suppiah, V. L., \& Imm, O. S. (2011). Attribution tendency and its relationship with actual and perceived poficiency. GEMA Online ${ }^{\circledR}$ Journal of Language Studies, 11(3), 199-218.

Nation, I. S. P. (1983). Testing and teaching vocabulary. Guidelines, 5(1), 12-25.

Nation, I. S. P., \& Yamamoto, A. (2012). Applying the four strands. International Journal of Innovation in English Language Teaching and Research, 1(2), 167-181.

Nation, P. (2006). Language education - vocabulary. In K. Brown (Ed.), Encyclopedia of Language \& Linguistics (Second Edition) (pp. 494-499). Oxford: Elsevier. Retrieved from http://www.sciencedirect.com/science/article/pii/B 0080448542006787

Nation, I. S. P. (2012). The BNC/COCA word family lists. Retrieved May 5, 2018, from https://www.victoria.ac.nz/lals/about/staff/publicat ions/paul-nation/Information-on-the-BNC_COCAword-family-lists.pdf.

Nurweni, A., \& Read, J. (1999). The English vocabulary knowledge of Indonesian university students. English for Specific Purposes, 18(2), 161-175. doi: 10.1016/S0889-4906(98)00005-2

Pallant, J. (2011). SPSS survival manual: A step by step guide to data analysis using SPSS (4th ed.). McGraw-Hill Education.

Renandya, W. A., Hamied, F. A., \& Nurkamto, J. (2018). English language proficiency in Indonesia: Issues and prospects. The Journal of Asia TEFL, 15(3), 618-629. doi: 10.18823/asiatefl.2018.15.3.4.618

Richards, H., Conway, C., Roskvist, A., \& Harvey, S. (2013). Foreign language teachers' language proficiency and their language teaching practice. The Language Learning Journal, 41(2), 231-246. doi: 10.1080/09571736.2012.707676
Richards, J. C. (2017). Teaching English through English: Proficiency, pedagogy and performance. RELC Journal, 48(1), 7-30. doi: $10.1177 / 0033688217690059$

Richards, J. C., \& Farrell, T. S. C. (2005). Professional development for language teachers: Strategies for teacher learning. Cambridge: Cambridge University Press. Retrieved from http://ebooks.cambridge.org/ref/id/CBO97805116 67237.

Schmid, Monika S., \& Mehotcheva, T. (2012). Foreign language attrition. Dutch Journal of Applied Linguistics, 1(1), 102-124. doi: 10.1075/dujal.1.1.08sch.

Schmitt, N., Schmitt, D., \& Clapham, C. (2001). Developing and exploring the behaviour of two new versions of the Vocabulary Levels Test. Language Testing, 18(1), 55-88. doi: 10.1177/026553220101800103.

Webb, S. A., \& Chang, A. C.-S. (2012). Second language vocabulary growth. RELC Journal, 43(1), 113-126. doi: 10.1177/0033688212439367.

Webb, S., Sasao, Y., \& Ballance, O. (2017). The updated Vocabulary Levels Test: Developing and validating two new forms of the VLT. International Journal of Applied Linguistics, 168(1), 34-70. doi: 10.1075/itl.168.1.02web

Widiati, U., \& Hayati, N. (2015). Teacher professional education in Indonesia and ASEAN 2015: Lessons learned from English language teacher education programs. In R. Stroupe \& K. Kimura (eds.), ASEAN integration and the role of English language teaching (pp. 121-148). Phnom Penh, Cambodia: IDP Education (Cambodia).

Widodo, A., \& Riandi. (2013). Dual-mode teacher professional development: Challenges and revisioning future TPD in Indonesia. Teacher Development, 17(3), 380-392. doi: 10.1080/13664530.2013.813757. 